九州大学学術情報リポジトリ

Kyushu University Institutional Repository

\title{
Statistical Analysis of Threshing Characteristics of Impact-type Rice Plant Threshing Device
}

Choe, Jung Seob

Department of Precision Mechanical Engineering, Kyungpook National University

Inoue, $\mathrm{Ei} \mathrm{j} \mathrm{i}$

Department of Bioproduction Environmental Science, Graduate School of Kyushu University

Mitsuoka, Muneshi

Department of Bioproduction Environmental Science, Graduate School of Kyushu University

Okayasu, Takashi

Department of Bioproduction Environmental Science, Graduate School of Kyushu University

他

https://doi.org/10.5109/26163

出版情報: 九州大学大学院農学研究院紀要. 58 (1)，pp.69-78，2013-02. Faculty of Agriculture， Kyushu University

バージョン：

権利関係: 


\title{
Statistical Analysis of Threshing Characteristics of Impact-type Rice Plant Threshing Device
}

\author{
Jung Seob CHOE ${ }^{1}$, Eiji INOUE ${ }^{2}$, Muneshi MITUSOKA ${ }^{2 *}$, Takashi OKAYASU ${ }^{2}$ \\ and Yasumaru HIRAI ${ }^{2}$
}

(Received October 31, 2012 and accepted November 8, 2012)

\begin{abstract}
An impact-type threshing device that applies perpendicular force to rice ear was developed in this study. Threshing experiment was performed for a single ear and to a bundle of rice plants. Crop properties and collision conditions were used as input parameters in this experiment to perform multiple regression analysis, thereby estimating threshing rate and percentage of grains with rachis branch. Optimal regression model for estimating threshing rate and percentage of grains with rachis branch was obtained for both single ear and bundle of rice plants. Although all four regression models had low analytical error and verification error, but relative error was high due to insufficient number of datasets and accuracy was low as a result. However, certain extent of estimation was possible for threshing rate. Observing that threshing rate was highly correlated with transverse threshing force and transverse displacement, it was inferred that threshing of rice plant by impact-type threshing device is from perpendicular force acting on rice ears. Although estimation of percentage of grains with rachis branch had low absolute error, accuracy was low because of relative error that is enlarged due to low rate of occurrence. Since percentage of grains with rachis branch was negatively correlated with net's mesh size, we concluded that the mesh size must be made as low as possible to reduce percentage of grains with rachis branch.
\end{abstract}

Key words: impact-type threshing device, multiple regression analysis, percentage of grains with rachis branch, threshing rate

\section{INTRODUCTION}

Agricultural population in Korea and Japan is significantly declining each year, with concurrent increase in the ratio of aged population. Accordingly, number of farming houses will rapidly decrease, actually leading to enlarged farming size and heightened demand for large and highly efficient agricultural machinery. Head feed combine, which was developed in Japan as a rice plant harvester, has increased in size and efficiency over the years and has achieved significant improvement. However, its threshing and selection functions are still not satisfactory.

Head feed combine differs from common combine; common combine draws all cut crops into the threshing drum for threshing, while head feed combine transfers the rice plant stems cut from the cutting part by carrier chain and supplies only $40 \mathrm{~cm}$ from the tip of the rice ear to the threshing part, thereby lowering threshing energy and increasing selection efficiency.

However, longitudinal threshing by strike from threshing teeth, which has been used since development of head feed combine, creates many straws and makes selection difficult (Umeda Mikio, 1992 (Part 1, 2)). This leads to significant amount of grain loss. Also, strong striking force during threshing damages the rice grain. These factors necessitate an improvement in the threshing method.

In addition, the bottleneck in developing high-effi-

\footnotetext{
1 Department of Precision Mechanical Engineering, Kyungpook National University, Korea

2 Department of Bioproduction Environmental Science, Graduate School of Kyushu University, Japan

* Corresponding author (E-mail: mitsuoka@bpes.kyushu-u.ac.jp)
}

ciency head feed combine by increasing cutting width or accelerating speed is the limitation in the selection performance (Umeda Mikio, 1992 (Part 3, 4)). Because selection performance is directly connected to threshing method, fundamental improvement in threshing method is even more direly needed.

We based our study on the finding from previous studies, which discovered that threshing by applying a force perpendicular to the rachis branch of a rice plant requires only half of the magnitude required in the longitudinal direction (Inoue E. et al., 2003) (Lee S. W. and Y. K. Huh, 1989) (Suastawa I. N. et al., 1996). The final goal in our study was to change the current threshing method that strikes paddies along the length of the rice plant to threshing in the perpendicular direction. As the first step, we manufactured impact-type threshing device that applies perpendicular force to rice ear. Threshing experiment was performed for a single rice ear without leaves and a bundle of 5 rice ears, with different net mesh sizes, collision speeds, etc., and threshing performances were evaluated.

Also, to estimate threshing rate and percentage of grains with rachis branch, multiple regression analysis was performed using grain properties and collision conditions as input parameters. From results of multiple regression analysis, effect of grain properties and collision conditions on threshing rate and percentage of grains with rachis branch was analyzed.

\section{MATERIALS AND METHODS}

Measurement of threshing force and displacement Measurement of threshing force

Threshing force was measured for Hinohikari rice 
plant grown in an artificial field at the Hakozaki campus of Kyushu University, Japan, using a tensile tester as in Fig. 1. First, rice grain and primary rachis branch were fixed with a stand and a clamp, and the moving part was moved downward at constant speed to stretch a small rachis branch. Tensile speed was $0.50 \mathrm{~mm} / \mathrm{s}$ and branch was about $10 \mathrm{~mm}$. Threshing force was measured using a small load cell (TOYO, TI, 1000120) from the start of movement by the moving part until the grain was expelled from the small rachis branch. Data was recorded using a data recorder (TEAC), and the maximum tensile force was set to be the threshing force.

Fig. 2 shows the method for fixing the grain and rachis branch in longitudinal and perpendicular direction when measuring threshing force. When measuring longitudinal threshing force, end of the primary rachis branch was fixed to the stand and the grain was fixed to the clamp. For measurement of perpendicular threshing force, the grain was fixed to the clamp on the stand side and the primary rachis branch was fixed to the clamp on the load cell side. When fixing the grain with a clamp, length of the clamp was made parallel to the length of the

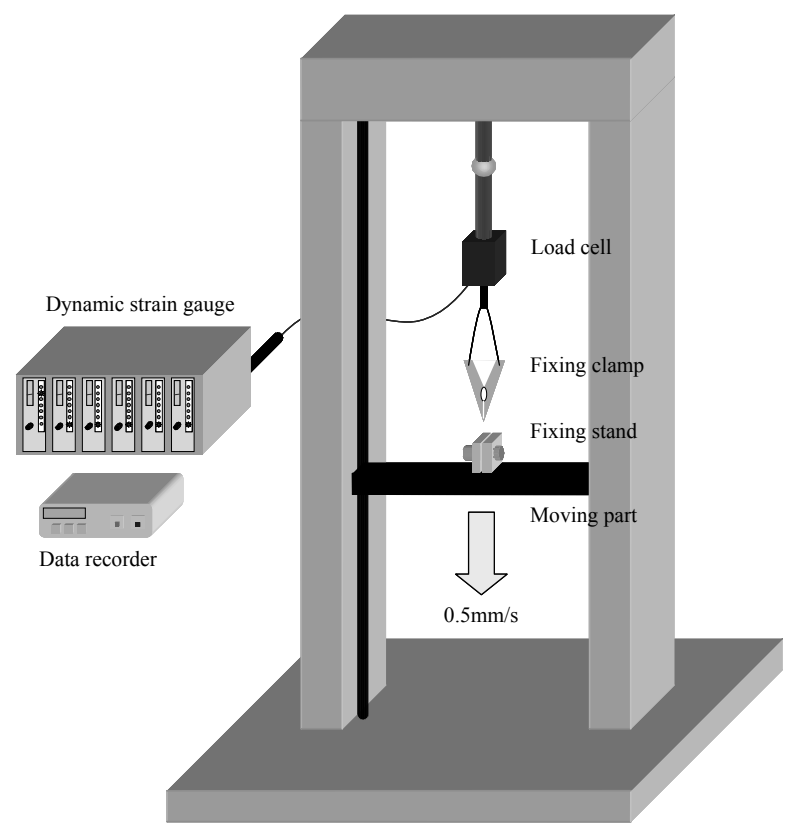

Fig. 1. Tensile tester.

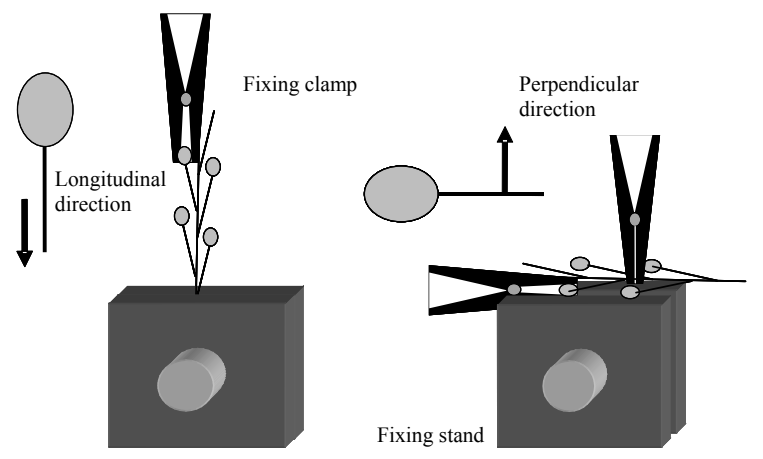

Fig. 2. Method for fixing an ear.

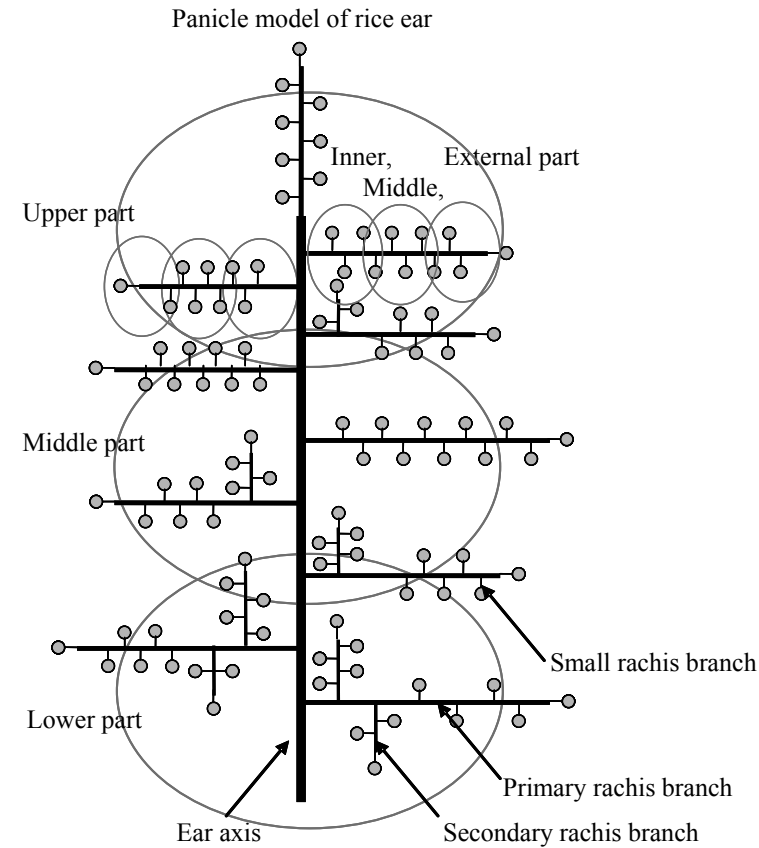

Fig. 3. Position of threshing force.

grain (Ichikawa Tomohiko and Takao Sugiyama, 1994).

Because threshing force differs for different parts of the ear, a grain from predetermined position in each ear was used for measurement to minimize the effect of measurement site. As shown in Fig. 3, ear was divided into the upper, middle, and lower part. One primary rachis branch was selected from each position, and this branch in turn was divided into external, middle, and inner part. Threshing force was measured for grains from each of these positions.

\section{Threshing displacement}

Generally at the start of a tensile test, predetermined initial load is applied while fibers are fully stretched but not elongated. It was assumed that tension between the grain and small rachis branch should also be defined for initial state in which the fibers between the grain and the small rachis branch are fully stretched but not elongated. Therefore, we referred to fiber tensile test method of JIS for the method for calculating displacement until the threshing.

According to the chemical fiber stability test in JISL1050 (1992), "draw initial load-displacement curve as in Fig. 4. Find the point $\mathrm{A}$ at which angle of the tangent line is maximum, and then designate the intersection of that tangent line with $\mathrm{x}$-axis as point T. Finally, set the point with $\mathrm{x}$-coordinate of point $\mathrm{T}$ as point $\mathrm{F}_{0}$, whose $\mathrm{y}$-coordinate is the initial load."

Meanwhile, an example of load-displacement curve that is obtained in measurement of threshing force is shown in Fig. 5. When moving part of the tensile tester elongates the fibers between the grain and the small rachis branch, tensile force (load) increases with displacement until threshing, at which point the load also disappears. As in the chemical fiber stability test in JIS- 


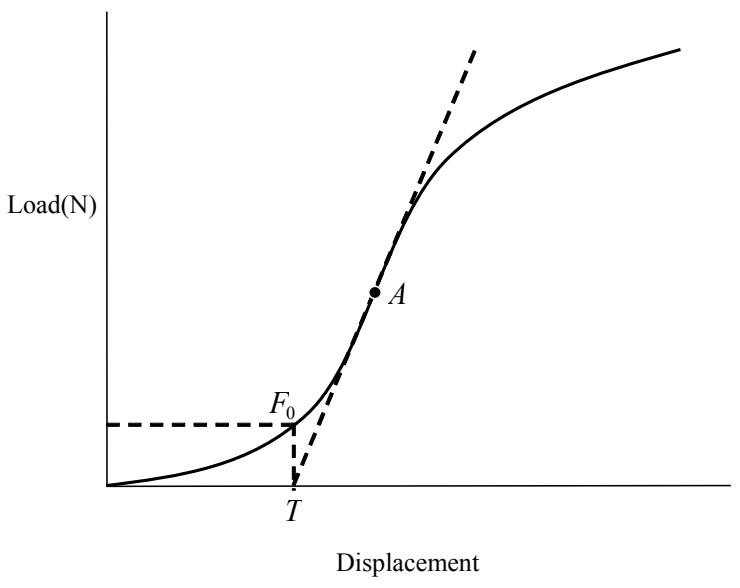

Fig. 4. Method for determining initial load in JISL1050 (1992).

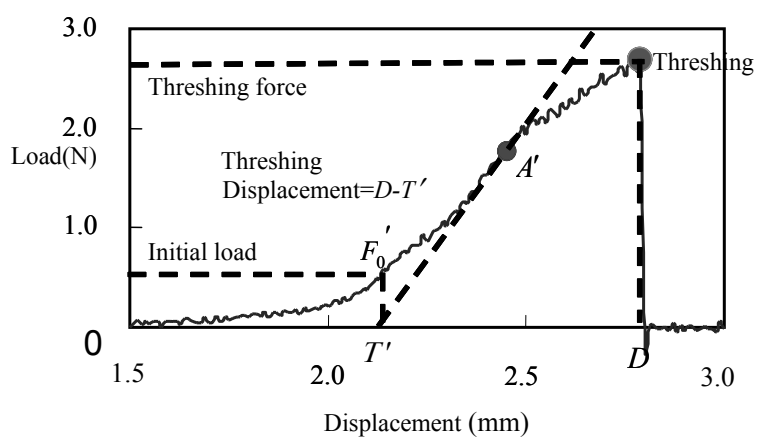

Fig. 5. Threshing load-rachis branch displacement.

L1050 (1992), tangent line was drawn from the point A' of maximum load change. The point of intersection between the tangent line and displacement axis was set as point T'. A perpendicular line starting from T' was drawn, and intersection of the line with load-displacement curve was designated as $\mathrm{F}_{0}$ '. Load corresponding to $\mathrm{F}_{0}$ ' was set as the initial load. However, actual measured values include slight variability, and initial load was determined not for displacement of $0 \mathrm{~mm}$ but $1.5 \mathrm{~mm}$ as in Fig. 5.

\section{Threshing experiment using impact-type threshing device}

An impact-type threshing device that can collide the net in the perpendicular direction of the rice ear was developed. Threshing experiment was performed for a single rice ear without leaves and a bundle of 5 rice ears with different net mesh sizes and collision speeds.

\section{Experimental apparatus}

In order to apply only perpendicular force to the rice ear, the device was designed such that the ear was not fixed and hung at about $30 \mathrm{~cm}$ from the end of the ear, and the ear would move with the net after collision. Steel bars with $2.0 \mathrm{~mm}$ diameter were placed equidistant in the net, as in Fig. 6. Interval between steel bars was set to $8,10,12$, and $14 \mathrm{~mm}$. Movement speed of the net can

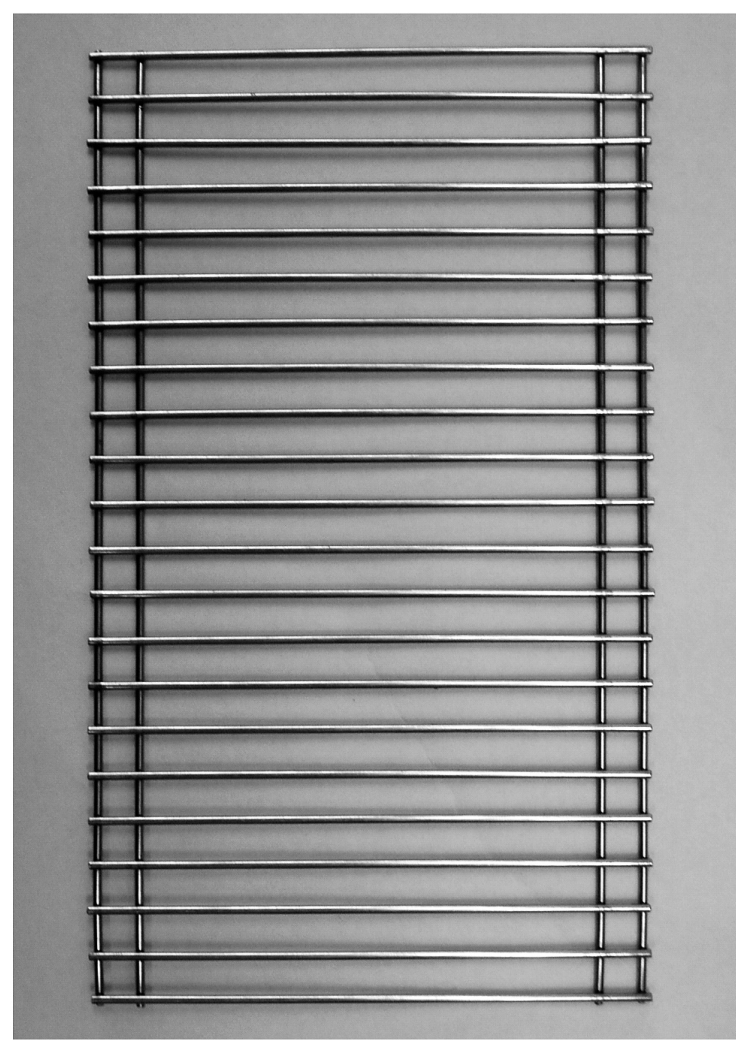

Fig. 6. Impact-type threshing device (threshing net).

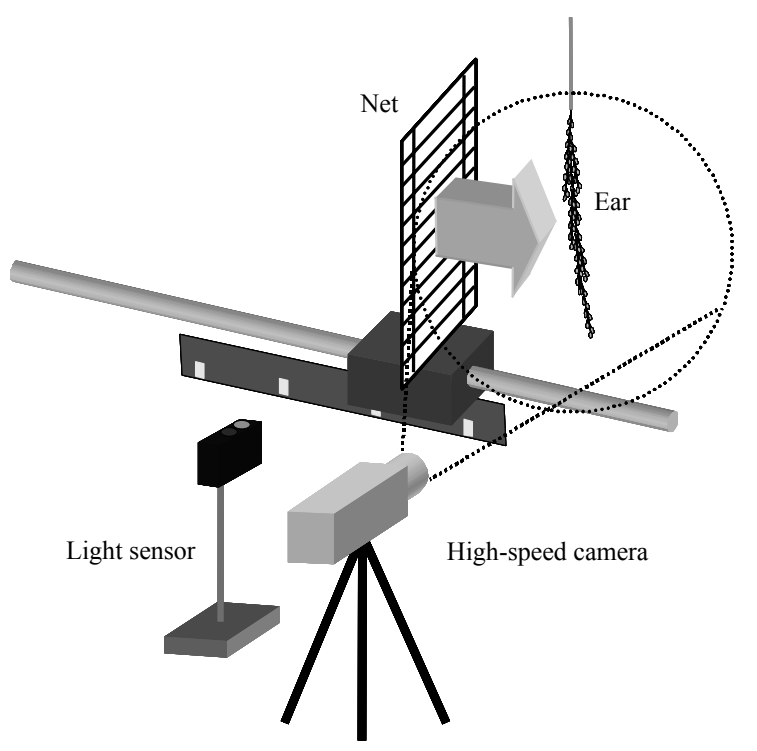

Fig. 7. Collision test equipment.

be controlled from $0 \sim 17 \mathrm{~m} / \mathrm{s}$ in continuous interval. For measurement of collision speed, reflection tapes were attached in horizontal direction in $10 \mathrm{~cm}$ intervals on the net table and a light sensor was used to measure pulse interval when the net passes. From the pulse intervals, average speed between each reflection tapes was calculated. Collision speed was defined as average speed between $10 \mathrm{~cm}$ before collision to $10 \mathrm{~cm}$ after collision. Configuration of experimental apparatus is as in Fig. 7. 


\section{Experimental procedure}

Threshing force and displacement in longitudinal and transverse direction for rice grain at designated location were measured 5 times for each condition to obtain the average values before performing the impact test.

In the single-ear threshing experiment, number of grains and chaffs to be used were counted before the experiment. For 5-ear bundle experiment, weight of the ears was measured, and then the net was collided into the ears. At this time, high-speed camera was used to capture images of threshing and scattering of grains, and light sensor was used to measure speed of the net. Next, grains were collected and grains threshed, grains with unthreshed head, and grains with rachis branch were counted or weighed. This process was repeated at maximum 6 times, and then grains and chaffs left on the ears were counted or weighed.

Due to limitations of experimental material and methods, number of data collected was insufficient. 32 datasets were collected for single-ear experiment and 17 datasets were collected for bundle experiment for regression analysis.

\section{Multiple regression analysis}

Grain properties and collision conditions from the threshing experiment by impact-type threshing device were used as input parameters in this experiment to perform multiple regression analysis, thereby estimating threshing rate and percentage of grains with rachis branch. Also, effect of crop properties and collision parameters on threshing rate and percentage of grains with rachis branch was evaluated using multiple regression results.

Multiple regression analysis uses multiple explanatory variables to predict a single target variable. It can be used to measure the extent of effect from each explanatory variable on the target variable (Ueda Taichiro et al., 2004). In this study, multiple regression analysis was performed in order to predict threshing rate and percentage of grains with rachis branch from multiple crop properties and collision conditions. 26 datasets from total of 32 datasets was used for the regression analysis for single-ear experiment, and the other 6 datasets were used to verify accuracy of prediction by the multiple regression prediction equation. For the bundle experiment, 14 datasets were used for analysis and 3 datasets were used for verification.

Threshing rate and percentage of grains with rachis branch were set as target variables (non-explanatory variables). Total of 7 explanatory variables were used, including 5 crop properties and 2 collision conditions. The crop properties were: weight of a single grain (hereafter referred to as grain weight), longitudinal threshing force (along the length of the ear), longitudinal displacement, and perpendicular threshing force. The collision conditions were net's mesh size and net speed. In order to use crop properties and collision conditions as explanatory variables, it is necessary to check correlation between the target variables (threshing rate and percentage of grains with rachis branch) and these explanatory varia- bles. For this purpose, we obtained correlation coefficient $(r)$ between threshing rate or percentage of grains with rachis branch with crop properties or collision conditions and then performed two-tailed t-test using Eq. 1 at $5 \%$ significance level for determining crop properties and collision conditions to be used as explanatory variables.

$$
t=\frac{|r| \sqrt{n-2}}{\sqrt{1-r^{2}}}
$$

Also, explanatory variable selection criteria $R u$, which can be obtained using Eq. 2, was used for determination of optimal model for multiple regression analysis(Makabe Hazime et al., 1989).

$$
R u=1-\left(1-R^{2}\right) \frac{n+k+1}{n-k-1}
$$

$R$ : multiple correlation

$n$ : number of data

$k$ : number of explanatory variables

Finally, mean of error in estimation obtained from inputting analysis data into the prediction equation of the optimal model compared to actual measurements (hereafter referred to as mean of analytical error) was obtained, as well as mean of error in estimation obtained from inputting verification data into the prediction equation compared to actual measurements (hereafter referred to as mean of verification error).

\section{RESULTS AND DISCUSSION}

\section{Threshing rate of single ear}

Table 1 shows experimental results used for multiple regression analysis of threshing rate, and Table 2 shows correlation coefficients between crop properties or collision conditions with threshing rate obtained from the experimental results.

Variables shown to have significant correlation with threshing rate by Eq. 1 were longitudinal displacement, transverse threshing force, transverse threshing force, and net speed. Therefore, these 4 variables were used as explanatory variables in multiple regression analysis. The results are shown in Table 3.

Because $p$-value of longitudinal displacement was largest, multiple regression analysis was performed again only for the other 3 explanatory variables. For this analysis, $\mathrm{p}$-value of transverse displacement was largest and multiple regression analysis was performed for the other 2 explanatory variables (Table 3 ).

Because the case with three explanatory variables had the largest $\mathrm{Ru}$ value, it was determined as the optimal regression model. Estimation value from the optimal model and actual measurements are shown in Fig. 8. Mean of analytical error was $5.52 \%$, mean of verification error was $6.72 \%$, and relative error was about $10 \%$.

\section{Percentage of grains with rachis branch of single ear}

Table 4 shows experimental results used for multiple 
Table 1. Results of single-ear threshing rate experiment

\begin{tabular}{|c|c|c|c|c|c|c|c|c|}
\hline & $\begin{array}{l}\text { Grain } \\
\text { weight (g) }\end{array}$ & $\begin{array}{l}\text { L. T- } \\
\text { force }(\mathrm{N})\end{array}$ & $\begin{array}{l}\mathrm{L}- \\
\text { disp. (mm) }\end{array}$ & $\begin{array}{l}\mathrm{T} . \mathrm{T}- \\
\text { force }(\mathrm{N})\end{array}$ & $\begin{array}{l}\mathrm{T}- \\
\text { disp. (mm) }\end{array}$ & $\begin{array}{l}\text { Net's mesh } \\
\text { size (mm) }\end{array}$ & $\begin{array}{l}\text { Net speed } \\
(\mathrm{m} / \mathrm{s})\end{array}$ & $\begin{array}{l}\text { Threshing } \\
\text { rate (\%) }\end{array}$ \\
\hline \multirow{26}{*}{$\begin{array}{l}\text { Analysis } \\
\text { data }\end{array}$} & $2.617 \mathrm{E}-02$ & 2.223 & 0.610 & 1.060 & 0.780 & 10 & 12.434 & 11.597 \\
\hline & $2.617 \mathrm{E}-02$ & 2.223 & 0.610 & 1.060 & 0.780 & 10 & 13.854 & 15.314 \\
\hline & $2.617 \mathrm{E}-02$ & 2.223 & 0.610 & 1.060 & 0.780 & 10 & 15.240 & 22.058 \\
\hline & $2.617 \mathrm{E}-02$ & 2.223 & 0.610 & 1.060 & 0.780 & 10 & 16.550 & 29.378 \\
\hline & $2.614 \mathrm{E}-02$ & 2.258 & 0.686 & 1.168 & 0.782 & 12 & 17.229 & 36.951 \\
\hline & $2.654 \mathrm{E}-02$ & 2.252 & 0.734 & 1.042 & 0.839 & 10 & 17.008 & 38.503 \\
\hline & $2.673 \mathrm{E}-02$ & 2.057 & 0.650 & 0.925 & 0.723 & 10 & 16.256 & 42.214 \\
\hline & $2.614 \mathrm{E}-02$ & 2.258 & 0.686 & 1.168 & 0.782 & 10 & 17.008 & 42.743 \\
\hline & $2.944 \mathrm{E}-02$ & 1.431 & 0.629 & 0.376 & 0.642 & 10 & 11.868 & 42.815 \\
\hline & $2.666 \mathrm{E}-02$ & 1.952 & 0.659 & 1.036 & 0.710 & 10 & 16.262 & 46.398 \\
\hline & $2.944 \mathrm{E}-02$ & 1.431 & 0.629 & 0.376 & 0.642 & 10 & 13.137 & 48.554 \\
\hline & $2.614 \mathrm{E}-02$ & 2.258 & 0.686 & 1.168 & 0.782 & 8 & 17.022 & 50.052 \\
\hline & $2.426 \mathrm{E}-02$ & 2.591 & 0.592 & 0.824 & 0.627 & 10 & 16.314 & 51.001 \\
\hline & $2.673 \mathrm{E}-02$ & 2.057 & 0.650 & 0.925 & 0.723 & 12 & 16.221 & 51.510 \\
\hline & $2.426 \mathrm{E}-02$ & 2.591 & 0.592 & 0.824 & 0.627 & 12 & 16.315 & 52.037 \\
\hline & $2.426 \mathrm{E}-02$ & 2.591 & 0.592 & 0.824 & 0.627 & 14 & 16.289 & 53.387 \\
\hline & $2.614 \mathrm{E}-02$ & 2.258 & 0.686 & 1.168 & 0.782 & 14 & 17.077 & 60.573 \\
\hline & $2.614 \mathrm{E}-02$ & 2.258 & 0.686 & 1.168 & 0.782 & 10 & 19.344 & 62.090 \\
\hline & $2.944 \mathrm{E}-02$ & 1.431 & 0.629 & 0.376 & 0.642 & 10 & 16.601 & 63.751 \\
\hline & $2.428 \mathrm{E}-02$ & 2.742 & 0.540 & 0.702 & 0.593 & 10 & 16.072 & 65.302 \\
\hline & $2.944 \mathrm{E}-02$ & 1.431 & 0.629 & 0.376 & 0.642 & 10 & 15.002 & 68.389 \\
\hline & $2.999 \mathrm{E}-02$ & 1.431 & 0.629 & 0.376 & 0.642 & 10 & 15.002 & 68.668 \\
\hline & $2.262 \mathrm{E}-02$ & 1.921 & 0.488 & 0.721 & 0.503 & 10 & 16.124 & 72.639 \\
\hline & $2.475 \mathrm{E}-02$ & 2.223 & 0.475 & 0.694 & 0.581 & 10 & 16.635 & 76.535 \\
\hline & $2.556 \mathrm{E}-02$ & 2.062 & 0.488 & 0.476 & 0.503 & 10 & 16.339 & 82.546 \\
\hline & $2.914 \mathrm{E}-02$ & 1.635 & 0.530 & 0.463 & 0.617 & 10 & 17.008 & 84.101 \\
\hline \multirow{6}{*}{$\begin{array}{l}\text { Verification } \\
\text { data }\end{array}$} & $2.614 \mathrm{E}-02$ & 2.258 & 0.686 & 1.168 & 0.782 & 10 & 12.888 & 17.571 \\
\hline & $2.666 \mathrm{E}-02$ & 1.952 & 0.659 & 1.036 & 0.710 & 12 & 16.137 & 35.851 \\
\hline & $2.673 \mathrm{E}-02$ & 2.057 & 0.650 & 0.925 & 0.723 & 10 & 16.256 & 44.441 \\
\hline & $2.426 \mathrm{E}-02$ & 2.591 & 0.592 & 0.824 & 0.627 & 8 & 16.370 & 53.639 \\
\hline & $2.428 \mathrm{E}-02$ & 2.742 & 0.420 & 0.702 & 0.484 & 10 & 16.072 & 67.129 \\
\hline & $2.853 \mathrm{E}-02$ & 1.205 & 0.473 & 0.316 & 0.590 & 10 & 17.008 & 78.718 \\
\hline
\end{tabular}

'L.T-force' is 'Longitudinal threshing force' and 'L-disp.' is 'Longitudinal displacement',

'T.T-force' is 'Transverse threshing force' and 'T-disp.' is 'Transverse displacement'.

Table 2. Correlation coefficients between threshing rate and crop properties or collision conditions in the single-ear experiment

\begin{tabular}{ccccccc}
\hline $\begin{array}{l}\text { Grain } \\
\text { weight }\end{array}$ & $\begin{array}{l}\text { Longitudinal } \\
\text { Threshing force }\end{array}$ & $\begin{array}{l}\text { Longitudinal } \\
\text { displacement }\end{array}$ & $\begin{array}{l}\text { Transverse } \\
\text { Threshing force }\end{array}$ & $\begin{array}{l}\text { Transverse } \\
\text { displacement }\end{array}$ & $\begin{array}{l}\text { Net's } \\
\text { mesh size }\end{array}$ & $\begin{array}{l}\text { Net } \\
\text { speed }\end{array}$ \\
\hline 0.052 & -0.254 & -0.482 & -0.575 & -0.721 & $3.000 \mathrm{E}-02$ & 0.405 \\
\hline
\end{tabular}

Table 3. Results of regression analysis of threshing rate in the single-ear experiment

\begin{tabular}{|c|c|c|c|c|c|c|}
\hline \multicolumn{3}{|c|}{$\begin{array}{l}\text { Number of } \\
\text { explanatory variables }\end{array}$} & \multirow{2}{*}{$\begin{array}{l}\text { Parameter } \\
\text { Intercept }\end{array}$} & \multirow{2}{*}{$\frac{\mathrm{t}}{0.34}$} & \multirow{2}{*}{$\frac{\mathrm{P} \text {-value }}{0.74}$} & \multirow{2}{*}{$\begin{array}{r}\text { Coefficient } \\
7.88\end{array}$} \\
\hline 4 & Multiple Correlation, $\mathrm{R}$ & 0.93 & & & & \\
\hline & Number of datasets & 26 & Longitudinaldisplacement & 0.51 & 0.62 & 23.52 \\
\hline & $\mathrm{Ru}$ & 0.80 & Transverse threshing force & -3.32 & $4.0 \times 10^{-3}$ & -32.49 \\
\hline & & & Transverse displacement & -2.13 & 0.04 & -98.30 \\
\hline & & & Net speed & 6.83 & $9.4 \times 10^{-7}$ & 7.76 \\
\hline \multirow[t]{4}{*}{3} & Multiple Correlation, $\mathrm{R}$ & 0.93 & Intercept & 0.37 & 0.72 & 8.49 \\
\hline & Number of datasets & 26 & Transverse threshing force & -3.95 & $6.8 \times 10^{-4}$ & -34.83 \\
\hline & $\mathrm{Ru}$ & 0.81 & Transverse displacement & -3.05 & $5.9 \times 10^{-3}$ & -79.13 \\
\hline & & & Net speed & 7.39 & $2.1 \times 10^{-7}$ & 7.92 \\
\hline \multirow[t]{3}{*}{2} & Multiple Correlation, $\mathrm{R}$ & 0.87 & Intercept & -2.52 & 0.02 & -44.48 \\
\hline & Number of datasets & 26 & Transverse threshing force & -8.69 & $1.0 \times 10^{-8}$ & -55.79 \\
\hline & $\mathrm{Ru}$ & 0.75 & Net speed & 7.48 & $1.3 \times 10^{-7}$ & 8.91 \\
\hline
\end{tabular}


regression analysis of percentage of grains with rachis branch, and Table 5 shows correlation coefficients between crop properties or collision conditions with per-

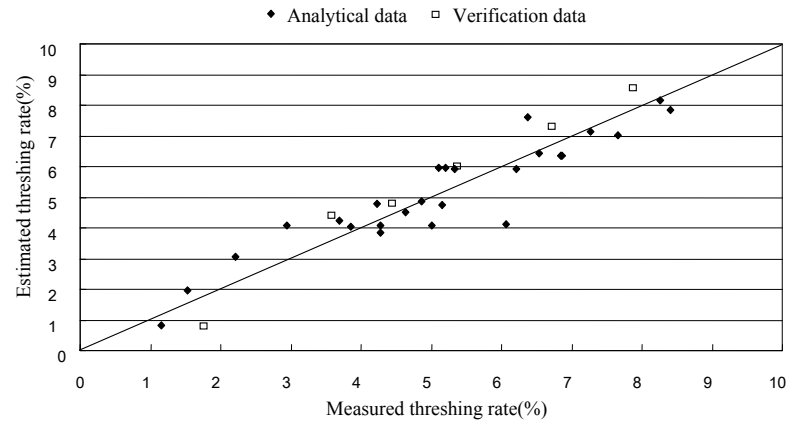

Fig. 8. Comparison of estimation and measurement of singleear threshing rate. centage of grains with rachis branch obtained from the experimental results.

Variables shown to have significant correlation with percentage of grains with rachis branch by Eq. 1 were grain weight, longitudinal threshing force, transverse threshing force, and net mesh size. Therefore, these 4 variables were used as explanatory variables in multiple regression analysis. The results are shown in Table 6 .

Because $\mathrm{p}$-value of longitudinal threshing force was largest, multiple regression analysis was performed again only for the other 3 explanatory variables. For this analysis, p-value of transverse threshing force was largest and multiple regression analysis was performed for the other 2 explanatory variables (Table 6).

Because the case with three explanatory variables had the largest Ru value, it was determined as the optimal

Table 4. Results of single-ear experiment for percentage of grains with rachis branch

\begin{tabular}{|c|c|c|c|c|c|c|c|c|}
\hline & $\begin{array}{l}\text { Grain } \\
\text { weight (g) }\end{array}$ & $\begin{array}{l}\text { L. T- } \\
\text { force }(\mathrm{N})\end{array}$ & $\begin{array}{l}\mathrm{L}- \\
\text { disp. (mm) }\end{array}$ & $\begin{array}{l}\text { T. T- } \\
\text { force }(\mathrm{N})\end{array}$ & $\begin{array}{l}\mathrm{T}- \\
\text { disp. }(\mathrm{mm})\end{array}$ & $\begin{array}{l}\text { Net's mesh } \\
\text { size (mm) }\end{array}$ & $\begin{array}{l}\text { Net speed } \\
(\mathrm{m} / \mathrm{s})\end{array}$ & $\begin{array}{l}\text { Threshing } \\
\text { rate }(\%)\end{array}$ \\
\hline \multirow{26}{*}{$\begin{array}{l}\text { Analysis } \\
\text { data }\end{array}$} & $2.944 \mathrm{E}-02$ & 1.431 & 0.629 & 0.376 & 0.642 & 10 & 16.601 & 0.163 \\
\hline & $2.914 \mathrm{E}-02$ & 1.635 & 0.530 & 0.463 & 0.617 & 10 & 17.008 & 0.231 \\
\hline & $2.999 \mathrm{E}-02$ & 1.431 & 0.629 & 0.376 & 0.642 & 10 & 15.002 & 0.375 \\
\hline & $2.944 \mathrm{E}-02$ & 1.431 & 0.629 & 0.376 & 0.642 & 10 & 13.137 & 0.603 \\
\hline & $2.944 \mathrm{E}-02$ & 1.431 & 0629 & 0.376 & 0.642 & 10 & 11.868 & 0.807 \\
\hline & $2.853 \mathrm{E}-02$ & 1.205 & 0.473 & 0.316 & 0.590 & 10 & 17.008 & 1.128 \\
\hline & $2.556 \mathrm{E}-02$ & 2.062 & 0.488 & 0.476 & 0.503 & 10 & 16.339 & 1.291 \\
\hline & $2.428 \mathrm{E}-02$ & 2.742 & 0.540 & 0.702 & 0.593 & 10 & 16.072 & 1.779 \\
\hline & $2.673 \mathrm{E}-02$ & 2.057 & 0.650 & 0.925 & 0.723 & 10 & 16.256 & 2.627 \\
\hline & $2.614 \mathrm{E}-02$ & 2.258 & 0.686 & 1.168 & 0.782 & 8 & 17.022 & 2.635 \\
\hline & $2.614 \mathrm{E}-02$ & 2.258 & 0.686 & 1.168 & 0.782 & 10 & 19.344 & 2.805 \\
\hline & $2.617 \mathrm{E}-02$ & 2.223 & 0.610 & 1.060 & 0.780 & 10 & 13.854 & 2.994 \\
\hline & $2.614 \mathrm{E}-02$ & 2.258 & 0.686 & 1.168 & 0.782 & 10 & 17.008 & 3.862 \\
\hline & $2.428 \mathrm{E}-02$ & 2.742 & 0.420 & 0.702 & 0.484 & 10 & 16.072 & 4.081 \\
\hline & $2.666 \mathrm{E}-02$ & 1.952 & 0.659 & 1.036 & 0.710 & 10 & 16.262 & 4.170 \\
\hline & $2.614 \mathrm{E}-02$ & 2.258 & 0.686 & 1.168 & 0.782 & 10 & 12.888 & 4.447 \\
\hline & $2.673 \mathrm{E}-02$ & 2.057 & 0.650 & 0.925 & 0.723 & 10 & 16.256 & 4.675 \\
\hline & $2.614 \mathrm{E}-02$ & 2.258 & 0.686 & 1.168 & 0.782 & 12 & 17.229 & 5.358 \\
\hline & $2.617 \mathrm{E}-02$ & 2.223 & 0.610 & 1.060 & 0.780 & 10 & 12.434 & 5.518 \\
\hline & $2.262 \mathrm{E}-02$ & 1.921 & 0.488 & 0.721 & 0.503 & 10 & 16.124 & 6.295 \\
\hline & $2.426 \mathrm{E}-02$ & 2.591 & 0.592 & 0.824 & 0.627 & 10 & 16.314 & 7.884 \\
\hline & $2.617 \mathrm{E}-02$ & 2.223 & 0.610 & 1.060 & 0.780 & 10 & 16.550 & 8.434 \\
\hline & $2.614 \mathrm{E}-02$ & 2.258 & 0.686 & 1.168 & 0.782 & 14 & 17.077 & 11.442 \\
\hline & $2.673 \mathrm{E}-02$ & 2.057 & 0.650 & 0.925 & 0.723 & 12 & 16.221 & 12.778 \\
\hline & $2.666 \mathrm{E}-02$ & 1.952 & 0.659 & 1.036 & 0.710 & 12 & 16.137 & 14.820 \\
\hline & $2.426 \mathrm{E}-02$ & 2.591 & 0.592 & 0.824 & 0.627 & 14 & 16.289 & 19.495 \\
\hline \multirow{6}{*}{$\begin{array}{l}\text { Verification } \\
\text { data }\end{array}$} & $2.944 \mathrm{E}-02$ & 1.431 & 0.629 & 0.376 & 0.642 & 10 & 15.002 & 0.546 \\
\hline & $2.475 \mathrm{E}-02$ & 2.223 & 0.475 & 0.694 & 0.581 & 10 & 16.635 & 1.535 \\
\hline & $2.654 \mathrm{E}-02$ & 2.252 & 0.734 & 1.042 & 0.839 & 10 & 17.008 & 2.709 \\
\hline & $2.426 \mathrm{E}-02$ & 2.591 & 0.592 & 0.824 & 0.627 & 8 & 16.370 & 4.444 \\
\hline & $2.617 \mathrm{E}-02$ & 2.223 & 0.610 & 1.060 & 0.780 & 10 & 15.240 & 6.768 \\
\hline & $2.426 \mathrm{E}-02$ & 2.591 & 0.592 & 0.824 & 0.627 & 12 & 16.315 & 13.091 \\
\hline
\end{tabular}

Table 5. Correlation coefficients between percentage of grains with rachis branch and crop properties or collision conditions in the single-ear experiment

\begin{tabular}{lcccccc}
\hline $\begin{array}{l}\text { Grain } \\
\text { weight }\end{array}$ & $\begin{array}{l}\text { Longitudinal } \\
\text { Threshing force }\end{array}$ & $\begin{array}{l}\text { Longitudinal } \\
\text { displacement }\end{array}$ & $\begin{array}{l}\text { Transverse } \\
\text { Threshing force }\end{array}$ & $\begin{array}{l}\text { Transverse } \\
\text { displacement }\end{array}$ & $\begin{array}{l}\text { Net's } \\
\text { mesh size }\end{array}$ \\
\hline-0.465 & 0.439 & 0.178 & 0.440 & 0.173 & 0.779 \\
speed
\end{tabular}


Table 6. Results of regression analysis of percentage of grains with rachis branch in the single-ear experiment

\begin{tabular}{clllrrr}
\hline $\begin{array}{l}\text { Number of } \\
\text { explanatory variables }\end{array}$ & & Parameter & $\mathrm{t}$ & P-value & Coefficient \\
\hline \multirow{2}{*}{4} & & & & & \\
& Multiple Correlation, $\mathrm{R}$ & 0.87 & Intercept & 0.09 & 0.93 & 1.73 \\
& Number of datasets & 26 & Grain weight & -1.75 & 0.09 & -910.26 \\
& $\mathrm{Ru}$ & 0.63 & Longitudinal Threshing force & -0.56 & 0.58 & -1.47 \\
& & & Transverse Threshing force & 1.48 & 0.15 & 3.37 \\
& & Net's mesh size & 6.29 & $3.1 \times 10^{-6}$ & 2.65 \\
\hline \multirow{2}{*}{3} & Multiple Correlation, $\mathrm{R}$ & 0.87 & Intercept & -0.61 & 0.55 & -6.58 \\
& Number of datasets & 26 & Grain weight & -2.10 & 0.05 & -686.99 \\
& Ru & 0.652 & Transverse Threshing force & 1.39 & 0.18 & 2.78 \\
& & & Net's mesh size & 6.36 & $2.1 \times 10^{-6}$ & 2.63 \\
\hline \multirow{2}{*}{2} & Multiple Correlation, $\mathrm{R}$ & 0.85 & Intercept & 0.08 & 0.94 & 0.77 \\
& Number of datasets & 26 & Grain weight & -3.08 & $5.2 \times 10^{-3}$ & 2.71 \\
& Ru & 0.649 & Net's mesh size & 6.47 & $1.3 \times 10^{-6}$ & -906.29 \\
\hline
\end{tabular}

regression model. Estimation value from the optimal model and actual measurements are compared in Fig. 9. Mean of analytical error was $1.83 \%$ and mean of verification error was $2.29 \%$, but relative error was about $70 \%$ and had low accuracy.

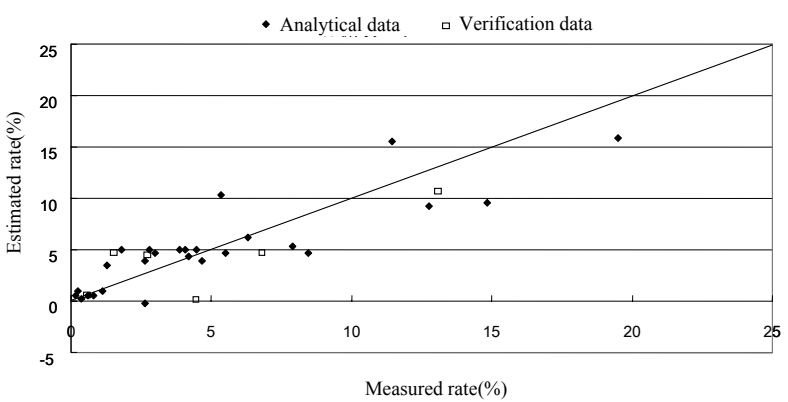

Fig. 9. Comparison of estimation and measurement of singleear percentage of grains with rachis branch.

\section{Threshing rate of bundle}

Table 7 shows experimental results used for multiple regression analysis of bundle threshing rate, and Table 8 shows correlation coefficients between crop properties or collision conditions with threshing rate obtained from the experimental results.

Variables shown to have significant correlation with threshing rate by Eq. 1 were grain weight, longitudinal threshing force, longitudinal displacement, transverse threshing force, and transverse displacement. Therefore, these 5 variables were used as explanatory variables in multiple regression analysis. The results are shown in Table 9 .

Because p-value of grain weight was largest, multiple regression analysis was performed again only for the other 4 explanatory variables. For this analysis, p-value of longitudinal threshing force was largest and multiple regression analysis was performed for the other 3 explanatory variables. Again, p-value of longitudinal displacement was largest and multiple regression analysis was performed for the other 2 explanatory variables (Table 9).

Table 7. Results of bundle threshing rate experiment

\begin{tabular}{llllllrrr}
\hline & $\begin{array}{l}\text { Grain } \\
\text { weight (g) }\end{array}$ & $\begin{array}{l}\text { L. T- } \\
\text { force (N) }\end{array}$ & $\begin{array}{l}\text { L- } \\
\text { disp. (mm) }\end{array}$ & $\begin{array}{l}\text { T. T- } \\
\text { force (N) }\end{array}$ & $\begin{array}{l}\text { T- } \\
\text { disp. (mm) }\end{array}$ & $\begin{array}{l}\text { Net's mesh } \\
\text { size (mm) }\end{array}$ & $\begin{array}{l}\text { Net speed } \\
(\mathrm{m} / \mathrm{s})\end{array}$ & $\begin{array}{l}\text { Threshing } \\
\text { rate (\%) }\end{array}$ \\
\hline Analysis & $2.681 \mathrm{E}-02$ & 2.239 & 0.733 & 0.902 & 0.716 & 10 & 13.107 & 8.395 \\
data & $2.586 \mathrm{E}-02$ & 2.261 & 0.803 & 0.961 & 0.742 & 10 & 17.392 & 24.110 \\
& $2.681 \mathrm{E}-02$ & 2.239 & 0.733 & 0.902 & 0.716 & 8 & 17.229 & 27.080 \\
& $2.681 \mathrm{E}-02$ & 2.239 & 0.733 & 0.902 & 0.716 & 12 & 17.242 & 30.499 \\
& $2.681 \mathrm{E}-02$ & 2.239 & 0.733 & 0.902 & 0.716 & 14 & 17.288 & 36.330 \\
& $2.681 \mathrm{E}-02$ & 2.239 & 0.733 & 0.902 & 0.716 & 10 & 20.072 & 43.182 \\
& $2.318 \mathrm{E}-02$ & 1.559 & 0.459 & 0.357 & 0.538 & 10 & 17.468 & 66.811 \\
& $2.699 \mathrm{E}-02$ & 1.312 & 0.451 & 0.361 & 0.579 & 10 & 17.483 & 73.512 \\
& $2.506 \mathrm{E}-02$ & 1.217 & 0.475 & 0.298 & 0.542 & 10 & 17.438 & 79.836 \\
& $2.402 \mathrm{E}-02$ & 1.350 & 0.423 & 0.319 & 0.604 & 8 & 17.053 & 84.449 \\
& $2.402 \mathrm{E}-02$ & 1.350 & 0.423 & 0.319 & 0.604 & 12 & 17.080 & 85.517 \\
Verification & $2.402 \mathrm{E}-02$ & 1.350 & 0.423 & 0.319 & 0.604 & 10 & 17.453 & 86.242 \\
data & $2.402 \mathrm{E}-02$ & 1.350 & 0.423 & 0.319 & 0.604 & 14 & 17.257 & 89.945 \\
& $2.402 \mathrm{E}-02$ & 1.350 & 0.423 & 0.319 & 0.604 & 10 & 19.325 & 92.579 \\
\hline
\end{tabular}


Table 8. Correlation coefficients between bundle threshing rate and crop properties or collision conditions

\begin{tabular}{lcccccc}
\hline $\begin{array}{l}\text { Grain } \\
\text { weight }\end{array}$ & $\begin{array}{l}\text { Longitudinal } \\
\text { Threshing force }\end{array}$ & $\begin{array}{l}\text { Longitudinal } \\
\text { displacement }\end{array}$ & $\begin{array}{l}\text { Transverse } \\
\text { Threshing force }\end{array}$ & $\begin{array}{l}\text { Transverse } \\
\text { displacement }\end{array}$ & $\begin{array}{l}\text { Net's } \\
\text { mesh size }\end{array}$ & $\begin{array}{l}\text { Net } \\
\text { speed }\end{array}$ \\
\hline-0.770 & -0.948 & -0.954 & -0.952 & -0.852 & 0.058 & 0.407 \\
\hline
\end{tabular}

Table 9. Results of regression analysis of bundle threshing rate

\begin{tabular}{|c|c|c|c|c|c|c|}
\hline \multicolumn{3}{|c|}{$\begin{array}{l}\text { Number of } \\
\text { explanatory variables }\end{array}$} & \multirow{2}{*}{$\begin{array}{l}\text { Parameter } \\
\text { Intercept }\end{array}$} & \multirow{2}{*}{$\begin{array}{c}\mathrm{t} \\
-0.45\end{array}$} & \multirow{2}{*}{$\begin{array}{l}\text { P-value } \\
0.66\end{array}$} & \multirow{2}{*}{$\begin{array}{c}\text { Coefficient } \\
-1413.46\end{array}$} \\
\hline 5 & Multiple Correlation, $\mathrm{R}$ & 0.97 & & & & \\
\hline & Number of datasets & 14 & Grain weight & 0.45 & 0.66 & 19806.74 \\
\hline & $\mathrm{Ru}$ & 0.84 & Longitudinal Threshing force & 0.45 & 0.66 & 383.56 \\
\hline & & & Longitudinal displacement & 0.46 & 0.66 & 956.98 \\
\hline & & & Transverse Threshing force & -0.50 & 0.63 & -1469.41 \\
\hline & & & Transverse displacement & 0.58 & 0.58 & 945.68 \\
\hline \multirow[t]{5}{*}{4} & Multiple Correlation, $\mathrm{R}$ & 0.97 & Intercept & -0.08 & 0.93 & -13.23 \\
\hline & Number of datasets & 14 & Longitudinal Threshing force & 0.07 & 0.95 & 3.82 \\
\hline & $\mathrm{Ru}$ & 0.86 & Longitudinal displacement & 0.12 & 0.90 & 24.59 \\
\hline & & & Transverse Threshing force & -0.83 & 0.43 & -164.01 \\
\hline & & & Transverse displacement & 1.43 & 0.17 & 227.80 \\
\hline \multirow[t]{4}{*}{3} & Multiple Correlation, $\mathrm{R}$ & 0.97 & Intercept & -0.05 & 0.96 & -4.70 \\
\hline & Number of datasets & 14 & Longitudinal displacement & 0.11 & 0.92 & 15.94 \\
\hline & $\mathrm{Ru}$ & 0.88 & Transverse Threshing force & -1.61 & 0.14 & -152.35 \\
\hline & & & Transverse displacement & 1.82 & 0.10 & 222.03 \\
\hline \multirow[t]{3}{*}{2} & Multiple Correlation, $\mathrm{R}$ & 0.97 & Intercept & 0.06 & 0.96 & 2.94 \\
\hline & Number of datasets & 14 & Transverse Threshing force & -5.84 & $1.1 \times 10^{-4}$ & -142.46 \\
\hline & $\mathrm{Ru}$ & 0.90 & Transverse displacement & 2.14 & 0.06 & 215.38 \\
\hline
\end{tabular}

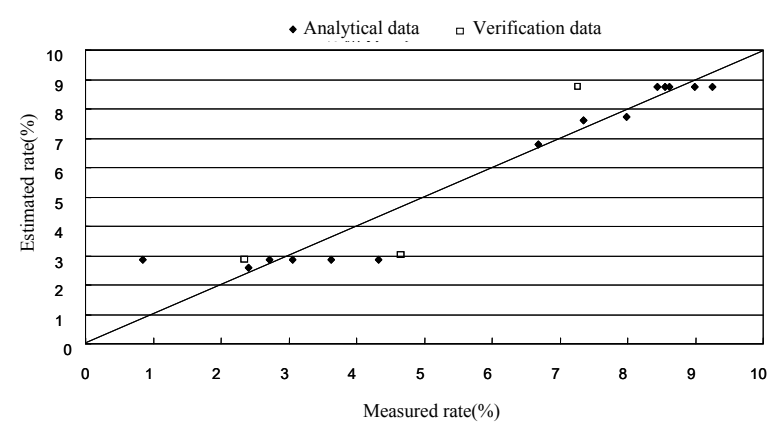

Fig. 10. Comparison of estimation and measurement of singleear threshing rate.

Because explanatory variable 2 had the largest $\mathrm{Ru}$ value, it was determined as the optimal regression model. Estimation value from the optimal model and actual measurements are compared in Fig. 10. Accuracy was not high as mean of analytical error was $4.86 \%$, mean of verification error was $12.26 \%$, and relative error was about $25 \%$.

\section{Percentage of grains with rachis branch of bundles}

Table 10 shows experimental results used for multiple regression analysis of percentage of grains with rachis branch for bundles, and Table 11 shows correlation coefficients between crop properties or collision conditions with percentage of grains with rachis branch obtained from the experimental results.
Variables shown to have significant correlation with percentage of grains with rachis branch by Eq. 1 were longitudinal displacement, transverse threshing force, and net mesh size. Therefore, these 3 variables were used as explanatory variables in multiple regression analysis. The results are shown in Table 12 .

Because $\mathrm{p}$-value of transverse threshing force was largest, multiple regression analysis was performed again only for the other 2 explanatory variables (Table 12).

Because explanatory variable 2 had the largest $\mathrm{Ru}$ value, it was determined as the optimal regression model. Estimation value from the optimal model and actual measurements are compared in Fig. 11. Mean of analytical error was $1.14 \%$ and mean of verification error was $0.78 \%$, but occurrence of grains with rachis branch was low as in the single-ear experiment and the relative error was $80 \%$, showing low accuracy.

26 datasets were used for single-ear and 14 datasets were used for bundle experiment for multiple regression analysis in this study, which is limited in reflecting characteristics of the population. However, estimation was possible to certain extent for threshing rate. Based on high correlation of threshing rate with transverse threshing force and transverse displacement, threshing of rice plant by impact-type threshing device can be thought to be from a force acting perpendicular to the rice ear.

Although estimation of percentage of grains with rachis branch had low absolute error, it is hard to expect high accuracy due to relative error that is increased by 
Table 10. Results of the bundle experiment for percentage of grains with rachis branch

\begin{tabular}{|c|c|c|c|c|c|c|c|c|}
\hline & $\begin{array}{l}\text { Grain } \\
\text { weight (g) }\end{array}$ & $\begin{array}{l}\text { L. T- } \\
\text { force }(\mathrm{N})\end{array}$ & $\begin{array}{l}\mathrm{L}- \\
\text { disp. (mm) }\end{array}$ & $\begin{array}{l}\text { T. T- } \\
\text { force }(\mathrm{N})\end{array}$ & $\begin{array}{l}\mathrm{T}- \\
\text { disp. (mm) }\end{array}$ & $\begin{array}{l}\text { Net's mesh } \\
\text { size (mm) }\end{array}$ & $\begin{array}{l}\text { Net speed } \\
(\mathrm{m} / \mathrm{s})\end{array}$ & $\begin{array}{l}\text { Threshing } \\
\text { rate (\%) }\end{array}$ \\
\hline \multirow{14}{*}{$\begin{array}{l}\text { Analysis } \\
\text { data }\end{array}$} & $2.402 \mathrm{E}-02$ & 1.350 & 0.423 & 0.319 & 0.604 & 10 & 19.325 & 0.251 \\
\hline & $2.402 \mathrm{E}-02$ & 1.350 & 0.423 & 0.319 & 0.604 & 8 & 17.053 & 0.492 \\
\hline & $2.402 \mathrm{E}-02$ & 1.350 & 0.423 & 0.319 & 0.604 & 10 & 17.453 & 0.643 \\
\hline & $2.402 \mathrm{E}-02$ & 1.350 & 0.423 & 0.319 & 0.604 & 10 & 12.888 & 0.667 \\
\hline & $2.506 \mathrm{E}-02$ & 1.217 & 0.475 & 0.298 & 0.542 & 10 & 17.438 & 0.769 \\
\hline & $2.681 \mathrm{E}-02$ & 2.239 & 0.733 & 0.902 & 0.716 & 10 & 13.107 & 1.084 \\
\hline & $2.681 \mathrm{E}-02$ & 2.239 & 0.733 & 0.902 & 0.716 & 8 & 17.229 & 1.089 \\
\hline & $2.402 \mathrm{E}-02$ & 1.350 & 0.423 & 0.319 & 0.604 & 14 & 17.257 & 1.236 \\
\hline & $2.402 \mathrm{E}-02$ & 1.350 & 0.423 & 0.319 & 0.604 & 12 & 17.080 & 1.347 \\
\hline & $2.318 \mathrm{E}-02$ & 1.559 & 0.459 & 0.357 & 0.538 & 10 & 17.468 & 2.658 \\
\hline & $2.535 \mathrm{E}-02$ & 2.654 & 0.654 & 0.839 & 0.681 & 10 & 17.258 & 2.689 \\
\hline & $2.681 \mathrm{E}-02$ & 2.239 & 0.733 & 0.902 & 0.716 & 10 & 20.072 & 3.169 \\
\hline & $2.586 \mathrm{E}-02$ & 2.261 & 0.803 & 0.961 & 0.742 & 10 & 17.392 & 4.509 \\
\hline & $2.681 \mathrm{E}-02$ & 2.239 & 0.733 & 0.902 & 0.716 & 14 & 17.288 & 10.933 \\
\hline \multirow{3}{*}{$\begin{array}{l}\text { Verification } \\
\text { data }\end{array}$} & $2.699 \mathrm{E}-02$ & 1.312 & 0.451 & 0.361 & 0.579 & 10 & 17.379 & 0.509 \\
\hline & $2.681 \mathrm{E}-02$ & 2.239 & 0.733 & 0.902 & 0.716 & 10 & 17.258 & 1.780 \\
\hline & $2.681 \mathrm{E}-02$ & 2.239 & 0.733 & 0.902 & 0.716 & 10 & 12.888 & 5.202 \\
\hline
\end{tabular}

Table 11. Correlation coefficients between percentage of grains with rachis branch and crop properties or collision conditions in the bundle experiment

\begin{tabular}{cccccc}
\hline $\begin{array}{l}\text { Grain } \\
\text { weight }\end{array}$ & $\begin{array}{l}\text { Longitudinal } \\
\text { Threshing force }\end{array}$ & $\begin{array}{l}\text { Longitudinal } \\
\text { displacement }\end{array}$ & $\begin{array}{l}\text { Transverse } \\
\text { Threshing force }\end{array}$ & $\begin{array}{l}\text { Transverse } \\
\text { displacement }\end{array}$ & $\begin{array}{l}\text { Net's } \\
\text { mesh size }\end{array}$ \\
\hline 0.481 & 0.513 & 0.557 & 0.551 & 0.486 & 0.537 \\
speed
\end{tabular}

Table 12. Results of regression analysis of percentage of grains with rachis branch in the bundle experiment

\begin{tabular}{|c|c|c|c|c|c|c|}
\hline \multicolumn{3}{|c|}{$\begin{array}{l}\text { Number of } \\
\text { explanatory variables }\end{array}$} & \multirow{2}{*}{$\begin{array}{l}\text { Parameter } \\
\text { Intercept }\end{array}$} & \multirow{2}{*}{$\begin{array}{c}\mathrm{t} \\
-1.96\end{array}$} & \multirow{2}{*}{$\begin{array}{c}\mathrm{P} \text {-value } \\
0.08\end{array}$} & \multirow{2}{*}{$\begin{array}{c}\text { Coefficient } \\
-13.96\end{array}$} \\
\hline 3 & Multiple Correlation, $\mathrm{R}$ & 0.80 & & & & \\
\hline & Number of datasets & 14 & Longitudinal displacement & 0.63 & 0.54 & 14.29 \\
\hline & $\mathrm{Ru}$ & 0.35 & Transverse Threshing force & -0.17 & 0.87 & -1.99 \\
\hline & & & Net's mesh size & 3.00 & 0.01 & 0.89 \\
\hline \multirow[t]{3}{*}{2} & Multiple Correlation, $\mathrm{R}$ & 0.80 & Intercept & -3.59 & $4.2 \times 10^{-3}$ & -12.94 \\
\hline & Number of datasets & 14 & Longitudinal displacement & 3.24 & $7.9 \times 10^{-3}$ & 10.52 \\
\hline & $\mathrm{Ru}$ & 0.44 & Net's mesh size & 3.14 & $9.5 \times 10^{-3}$ & 0.89 \\
\hline
\end{tabular}

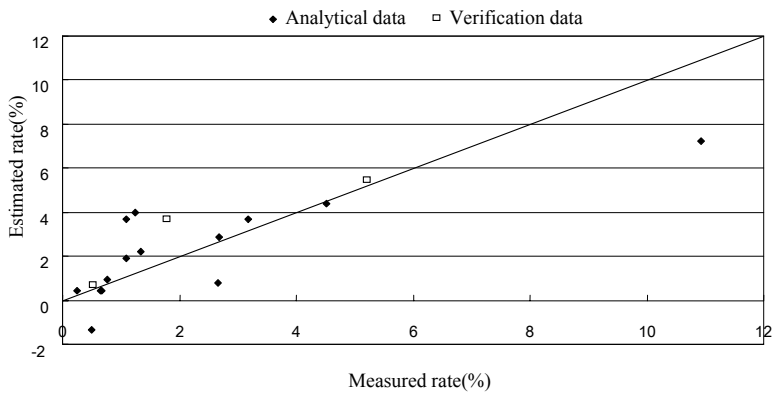

Fig. 11. Comparison of estimation and measurement of bundles percentage of grains with rachis branch.

low rate of occurrence. Nonetheless, the rate was inversely correlated with net mesh size and it can be inferred that the mesh size of the impact-type threshing device should be made as small as possible to reduce per- centage of grains with rachis branch.

\section{SUMMARY AND CONCLUSION}

In this study, an impact-type threshing device that applies perpendicular force to rice ear was developed. Threshing experiment was performed for a single rice ear without leaves and a bundle of 5 rice ears, with different net mesh sizes, collision speeds, etc., and threshing performances were evaluated. From results from this experiment, crop properties and collision conditions were used as input parameters to multiple regression analysis in order to estimate threshing rate and percentage of grains with rachis branch. Also, from results of multiple regression analysis, effect of grain properties and collision conditions on threshing rate and percentage of grains with rachis branch was analyzed. Main results are as follows. 
1. Longitudinal displacement, transverse threshing force, transverse displacement, and net speeds, which had statistically significant correlation with threshing rate of single ear, were used as explanatory variables in multiple regression analysis. The regression model expressed in terms of transverse threshing force, transverse displacement, and net speed, and excluding longitudinal displacement, was shown to be optimal. For this model, mean of analytical error was $5.52 \%$, mean of verification error was $6.72 \%$, and relative error was about $10 \%$.

2. Grain weight, longitudinal threshing force, transverse threshing force, and net mesh size, which had statistically significant correlation with percentage of grains with rachis branch of single ear, were used as explanatory variables in multiple regression analysis. The regression model expressed in terms of grain weight, transverse threshing rate, and net mesh size, and excluding longitudinal threshing force, was shown to be optimal. For this model, mean of analytical error was $1.83 \%$ and mean of verification error was 2.29\%. Although these errors were low, relative error was about $70 \%$ and the model's accuracy was low.

3. Grain weight, longitudinal threshing force, longitudinal displacement, transverse threshing force, and transverse displacement, which had statistically significant correlation with threshing rate of bundle, were used as explanatory variables in multiple regression analysis. The regression model expressed in terms of transverse threshing force and transverse displacement was shown to be optimal. This model had low accuracy as mean of analytical error was $4.86 \%$, mean of verification error was $12.26 \%$, and relative error was about $25 \%$.

4. Longitudinal displacement, transverse threshing force, and net mesh size, which had statistically significant correlation with percentage of grains with rachis branch of bundles, were used as explanatory variables in multiple regression analysis. The regression model expressed in terms of longitudinal displacement and net mesh size, and excluding transverse threshing force, was shown to be optimal. Mean of analytical error was 1.14\% and mean of verification error was $0.78 \%$, but occurrence of grains with rachis branch was low as in the single-ear experiment and the relative error was $80 \%$, showing low accuracy.

Number of datasets in this study may be insufficient in fully reflecting characteristics of the population, and accumulation of data is thought to be required in the future. Additionally, in order to expedite commercialization of impact-type threshing device, experiment should be performed for rice ears with leaves on them in order to collect data as close to the actual condition as possible. Also, threshing phenomenon should be understood in detail by taking into account interaction between grains. Such efforts will be needed to reduce various errors in estimating threshing phenomenon.

\section{ACKNOWLEDGEMENTS}

This Research was supported by Kyungpook National University Research Fund, 2012.

\section{REFERENCES}

Ichikawa Tomohiko and Takao Sugiyama 1994 Development of Testing Equipment for the Shattering Habit of Paddy (Part 1) Journal of the Japanese Society of Agricultural Machinery, 56(1): 101-107

Inoue E., Ikuo Ueka, Yasumaru Hirai, Masami Matui, Takashi Fukushima and Ken Mori 2003 Evaluation of Strength Distribution on Detachment Force of Paddy Grain, Sci. Bull. Fac. Agr., Kyushu Univ., 58(1, 2): 27-32

Lee S. W. and Y. K. Huh 1989 Threshing and Cutting Forces for Korean Rice, TRANSACTIONS of ASAE, 27(6): 1654-1657, 1660

Makabe Hazime, Tetsuo Miyamura and Kazuaki Suzuki 1989 Sinraiseimoderuno toukeikaiseki, Kyoritsu Shuppan Co., Ltd.(Tokyo, Japan)

Suastawa I. N., O. Kitani, N. Sakai, S. Yonekawa, T. Okamoto and T. Torii 1996 Grain Detachment Strength and Grain Mass of Three Rice Types. Journal of the Japanese Society of Agricultural Machinery, 58(1): 65-72

Ueda Taichiro, Maki Kobayashi and Miki Fuchigami 2004 Exceldemanabukaikibunseki nyumon, Ohmsha, Ltd. (Tokyo, Japan)

Umeda Mikio 1992 Analysis of Threshing Mechanism of Head Feeding Thresher (Part 1, 2, 3, 4), Journal of the Japanese Society of Agricultural Machinery, 54(1): 47-55, 54(2): $41-50, \mathbf{5 4}(3): 43-52, \mathbf{5 4}(4): 49-57$ 